fruit quality in glasshouse tomatoes (D. J. Stanton and D. Salter); bitter pit investigations in apples (E. T. Chittenden, J. Watson and L. Hodgson). The Director notes that, during the two years, investigations at the Institute - the work of which is restricted to plant nutrition and related soil studies, but includes fundamental investiga. tions-have included long-term studies of soils, apples, tomatoes and pastures, and, in collaboration with the Hop Research Station and the Tobacco Research Station of the Department of Scientific and Industrial Research, of tobacco and hops. These have included the study of hop diseases and the nutritional requirements of the black root-rot fungus (Phytophthora cactorum (Schroet)) and of other species of Phytophthora, and investigations of the chemical composition and smoking quality of tobacco. Other investigations in progress deal with: calcium metabolism of apples; the availability of magnesium to white clover and to pastures and apple trees from different fertilizers; the availability to pastures of phosphorus from different fertilizers; sulphur requirements of pastures on certain Nelson soils, and a systematic study of minor element status of soils of the Nelson province. Insufficient finance was forthcoming for a proposed scheme of research into sheep farming. The technical report notes a substantial reduction in bitter pit in Cox's Orange apples from the use of ealcium nitrate sprays and satisfactory results with sawdust as a rooting medium for nutrient trials with tomatoes. Investigations of various diseases and of Verticillium with disease of hops are also noted.

\section{The Technologist}

THe first issue of a new quarterly, entitled The Technolo gist: the Study of Technology and Society, includes an article by Lord Fleck "The Image of Technology", a bibliographical review by $K$. Hudson of industrial archæology and some comments on the Trend Report by A.ubrey Jones (1, No. 1, January 1964. Pp. xiv +42 . Published quarterly. London: Sir Isæac Pitman and Sons, Ltd., 1964. Annual subscription 30s. Single issues $78.6 d$.). A note on research in progress by $\mathrm{E}$. Hope deals with music composition by high-speed computer, and Dr. R. A. Buchanan under the title "Technology Comes of Age" discusses the status of technology in Britain. The periodical is a joint venture on the part of the publishers and the Bristol College of Science and Technology. Besides examining the impact of technology and the applied and social seiences on contemporary society, and the significance of the work of technological institutions, the periodical seeks to express the distinctive outlook of these institutions, explore the philosophical implications of technology, and promote the exchange of ideas between the institutions and Government and industry.

\section{Social Welfare Work in France}

A PAMPHLET, Social Welfare in France, issued by the Press and Information Service of the French Embassy, which describes the organization of social welfare work in France, gives a brief account also of the training and recruitment of welfare workers (Ambassade de France, Service de Presse et d'Information. Social Welfare Work in France. Pp. 14. London: Ambassade de France, Service de Presse et d'Information, 1963). Social welfare schools provide some 800 welfare workers a year, but recruitment, mainly women, is becoming more and more difficult and does not correspond with needs. This is attributed to the numerous other openings now available to girls, to the arduous and tiring nature of the work and to the unattractive remuneration and prospects.

\section{Technical Assistance in Economic Development}

Mr. A. Maddison, director for technical co-operation of the Organization for Eeonomic Co-operation and Development, has recently described the role of technical assistance in economic development (O.E.C.D. Observer.
December 1963). In this he outlines what is being done on a world scale to meet the needs of the developing countries for foreign skills, training and technology, and gives some comparative figures for the British contribution which should be noted. Although his figures for Britain's assistance are lower than those which have since been given by the Secretary for Technical Co-operation, according to Mr. Maddison Britain supplied 17,500 experts in 1962 to work in developing countries financed by technical assistance out of 85,000 from member countries of the O.E.C.D. Development Assistance Committee and of a world total of 102,500 . Britain received 40,000 students and trainees from these countries out of corresponding totals of 135,000 and 170,000 , respectively; France and the United States receiving 25,000 and 40,000 , respectively; and West Germany 15,000 .

\section{Radiation Control of Salmonellae}

Radiation preservation of foods is recoiving increasing attention as an alternative to using chemical preservatives. The sensitivity of organisms to ionizing radiation varies between species: Salmonella are not among the most resistant. The International Atomic Energy Agency, Vienna, has recently discussed this in No. 22 of its Technical Reports Series, entitled Radiation Control of Salmonellae in Food and Feed Products (Pp. 148. Vienna: International Atomic Energy Agency; London: H.M.S.O., 1963. 64 schillings; $188 . ; 3$ dollars). The report mentions that heat treatment is not totally effective in removing Salmonella, and the organisms are not revealed at a concentration less than 10-20 per kg of feed. On the other hand, irradiation of the order of $7-10 \times 10^{5}$ rads will reduce Salmonella by a factor of $10^{7}$. Doses of this order do not affect vory much the quality of the food or feed products. Losses of vitamins and protein, for example, are not significant at $0.5 \mathrm{M} \mathrm{rad}$ and irradiated blood albumin contains moro available lysine than the heat-treated material. A sample of chicken lost its irradiation odour and taste on placing in the refrigerator for $24 \mathrm{~h}$ and looked more appetizing than on unirradiated sample. Storage of irradiated food should be under refrigeration, as surviving organisms can multiply more quickly owing to lack of competition. The sensitivity of different serotypes of Salmonella to irradiation varies with the food medium, temperature and gaseous environment; the well-known oxygen effect, for example, being of the usual magnitude. Radiation preservation would be less costly than heat treatment. The cost of a plant would be mainly due to the cost of the isotope. Radiation doses of greater than 1 Mrad can cause off-odours and flavours. Fnzyme activity is not arrested even at the sterilizing dose. (There is a misprint in the first paragraph of p. 77, where '50,000 rad' should read '500,000 rads'.)

\section{Fossil Squirrels}

A RECENT issue of the Bulletin of the Museum of Comparative Zoology at Harvard College reviews thoroughly all the North American specimens of 'Tertiary Sciuridae, including many specimens not previously described; three new genera and seven now species are named (130, No. 3; December 20, 1963. A Review of the North Amer. ican Tertiary Sciuridae. Pp. 109-248+22 plates. Cambridge, Massachusetts: Museum of Comparative Zoology at Harvard College, 1963). The Sciuridae are known in North America from Mid-Oligocene times onward; some genera appear to have originated in North America and migrated later to other continents (for example, Marmotta), while other genera have remained exclusively American. The author, C. C. Black, broadly accepts the two-fold division of the Seiuridae into Petauristinae and Sciurinae, with recognition of eight tribes in the latter sub-family, though the generic grouping into tribes differs slightly from recent writers. Black mentions that the Petauristinae (flying squirrels) as a group are more of a convenience than a reflexion of monotaxic origin. $\mathrm{He}$ 